\title{
Agro-tourism in Rajasthan: A way to bring down issues in our surrounding environment
}

\author{
Hemani Kothari ${ }^{a}$, Dr. Asif Perwejs ${ }^{b}$ \\ ${ }^{a}$ Research Scholar, Sangam University, Bhilwara \\ ${ }^{\mathrm{b}}$ Assistant Professor, Sangam University, Bhilwara
}

Article History: Received: 10 November 2020; Revised 12 January 2021 Accepted: 27 January 2021; Published online: 5 April 2021

\begin{abstract}
The study attempts to show the impacts of agro tourism in environmental and climatic betterment of the state and nation. The results of this study will tell us that agro-tourism will help to improve environmental and climatic factors and also plays a great role as an additional income source for farmers and government. General public is now-a-day's facing problem because of environmental instability and this can be cured if we consider agro tourism sector as a solution and incorporate this sector too like other tourism sector. Maharashtra was the first to understand this sectors demand and used this concept very well to improve its GDP and environment. Agro tourism help to create awareness among public about the environment by providing income source and environmental benefits both simultaneously. It creates knowledge about agriculture science.

A modern style of development proposes rationalexploitation of agricultural resources together with the rediscovery of heritage both historical and naturalistic as a means to reach sustainable development. Agro tourism acts as the contact point between the tourist's expectations of healthy environment, natural and fresh products, rediscovery of nature and best touristic services with an unforgettable experience. The study assumes the importance of environmental and climatic betterment to neutralize or reduce its harmful effects in near future. It helps to evaluate that how a sustainable development can be reached without causing damage to our environment.

This synergy between agriculture and tourism capitalized on the combined benefits of development in agriculture as a primary sector and tourism as a service sector which further boost rural employment generation and environmental benefits.

Thus, the paper suggests that agro-tourism has the potential for developing income opportunities and creates new ways for environmental and climatic betterment.
\end{abstract}

Keywords: Sustainable Deveopment, Agro Tourism, Agriculture science, Synergy, Primary Sector, Service Sector

\section{Introduction}

The question of how to reduce environmental and climatic consequences has been long addressed by the government and this can be solved with the help of agro tourism. Agro-tourism can be defined in general terms as a combination of agriculture and tourism sector hand in hand or we can say that it is a kind o tourism in which tourists involves themselves in various village activities, crop care, animals care, handicrafts and other sources o entertainment. In this the tourists found a way to link with nature by doing various activities that involves picking an apple from tree, ride a bull cart, visit farms and stay in a house like farmers. Agro tourism is a sector which attracts the tourists to gain a new life time experience and also help to reduce the environmental and climatic consequences.

Agro tourism provides both enjoyment and education to visitors as it provides natural, environmental, cultural and historical assets of the land and the people working on it. Agro tourism helps to do sustainable development and also maintain the land's resources by providing income benefits to farmers, government and other peoples. It also helps to increase the flow of money in local markets by encouraging natural and organic food and things which do not harm nature. 


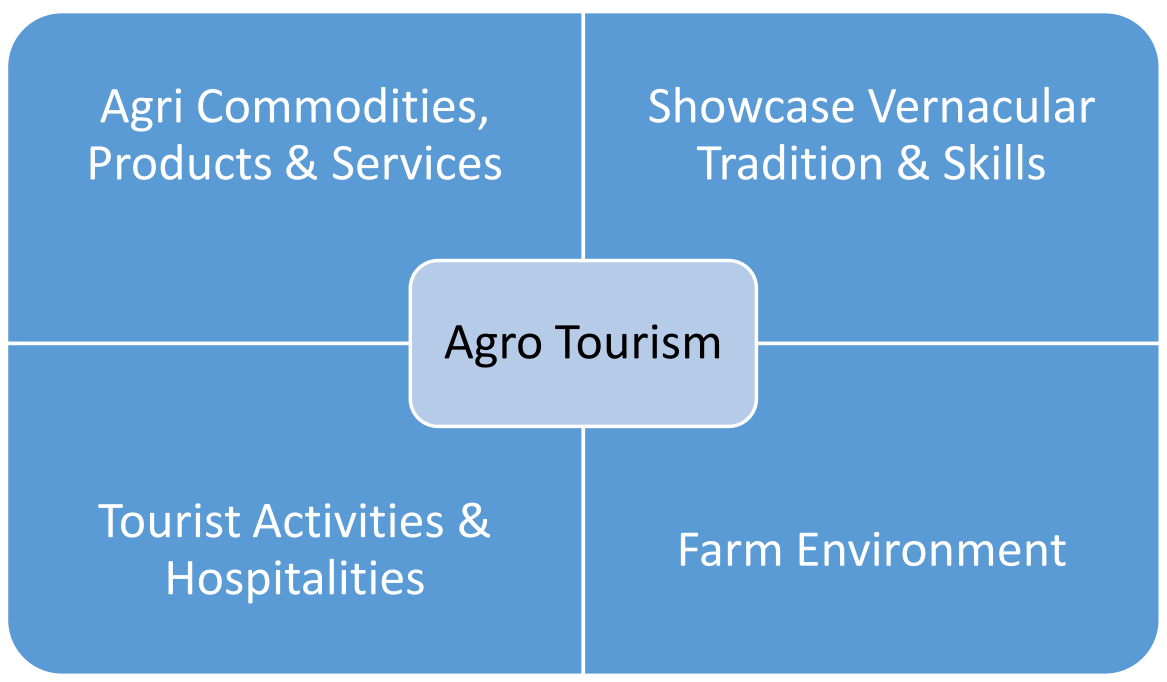

\section{Objectives}

The present study is an Experiment to know whether the Agro-Tourism helps in reducing environmental and climatic consequences, and initiatives taken by government to educate peoples about this new era of tourism and agriculture. This thought and idea will create an alternative source of income, engagement and pride.

Following are the objectives of present research;

1. To understand the importance of agro tourism for environmental and climatic betterment.

2. To give knowledge to the villagers that foreigner and other tourist visitors are their source of income.

3. To analyze agro tourism as a source of better climate and source of healthy food option.

4. To understand that how agro tourism is a sustainable way for the foreseeable future.

\section{Scope}

1. Cost effective: The cost for accommodation, food, living, and travel is low compared toother forms of tourism. Thus, widening the scope of agro tourism.

2. Exploring new era: urban segment is very curious about this form of tourism as they get a chance to explore so many new things and rediscover the rural life.

3. Full family oriented recreational activity: through rural customs, traditions, foods, festival celebrations and traditional wear.

4. Providing knowledge: about variety of ways of doing farming and agriculture science where students are moving with the pace of technology.

5. Nostalgia for their roots on the farm: for tourists it is like uniting with their roots.

\section{Theoretical Background}

In the last decades, lot of changes occurred in tourism and agriculture and one of which is agro tourism that is synergic benefit of agriculture and tourism. Rural communities have seen lot of shifts in economic activities and towards urban area that results in a problem in traditional structure and organisation of rural areas. If we compare from past lots of agricultural sites have been converted into residential or commercial sites which in short leads to decrease in quality of land and also increase the risk of economic, social, environmental and climatic decline.

Both tourism and agriculture is the most important sector in terms of employment, wealth and production. On may/16/2008, "WORLD AGRI TOURISM DAY" was celebrated for the first time in Pune, Maharashtra chief guest honrableshriBalasahebThorat-then Minister of agriculture. And Maharashtra was the first state that brings concept of Agro tourism in India.

We are losing our natural beauty and facing an abundance of healthy food choices. There is lot to protect, maintain, experience and enjoy. Like maintaining heritage, feel the nature, to live in a healthy environment, to eat fresh and organic food, to relive and maintain the connection between the nature and us. Agro tourism can also be termed as Eco tourism as it provides a sustainable development without causing harm to our surrounding or nature. Rural communities can look towards this concept as an opportunity torelocalise and rediscover local traditions and methods, authenticity and better way of living. 


\section{Responsible Travel Implementation}

The fact that certain place has great climatic condition, healthy environment, good cuisines and other experience worthy things does not mean that that place is ready for the tourism purpose. Before inviting the tourists at that place, the most important thing to decide about is that how to present and sustain their place and climate and protect their community from environmental and climatic consequences. Because the more tourists or visitors the more pollution, wastes and other harmful things too. So at first we need to implement some environment safety measures and enhance the ecotourism that leads to sustainable development and decrease in environmental and climatic consequences.

Responsible travel covers a lot o ground today. There are lot of related categories which are linked with each other in many ways, categories are- eco, ethical, sustainable, green, bio, geo, etc. The bottom line is that peoples are working to protect their community in which they live or visit and to protect it too. It is the responsibility of tourists to take proper care about the environment and surrounding where they visit. by promoting the concept of agro-tourism problem of environmental and climatic consequences can be reduced as it provides income generation from agricultural sites which leads to increase in agricultural sites and hence results in lesser damage to environment and climate.

\section{Rajasthan Action Plan on climate change approach:-}

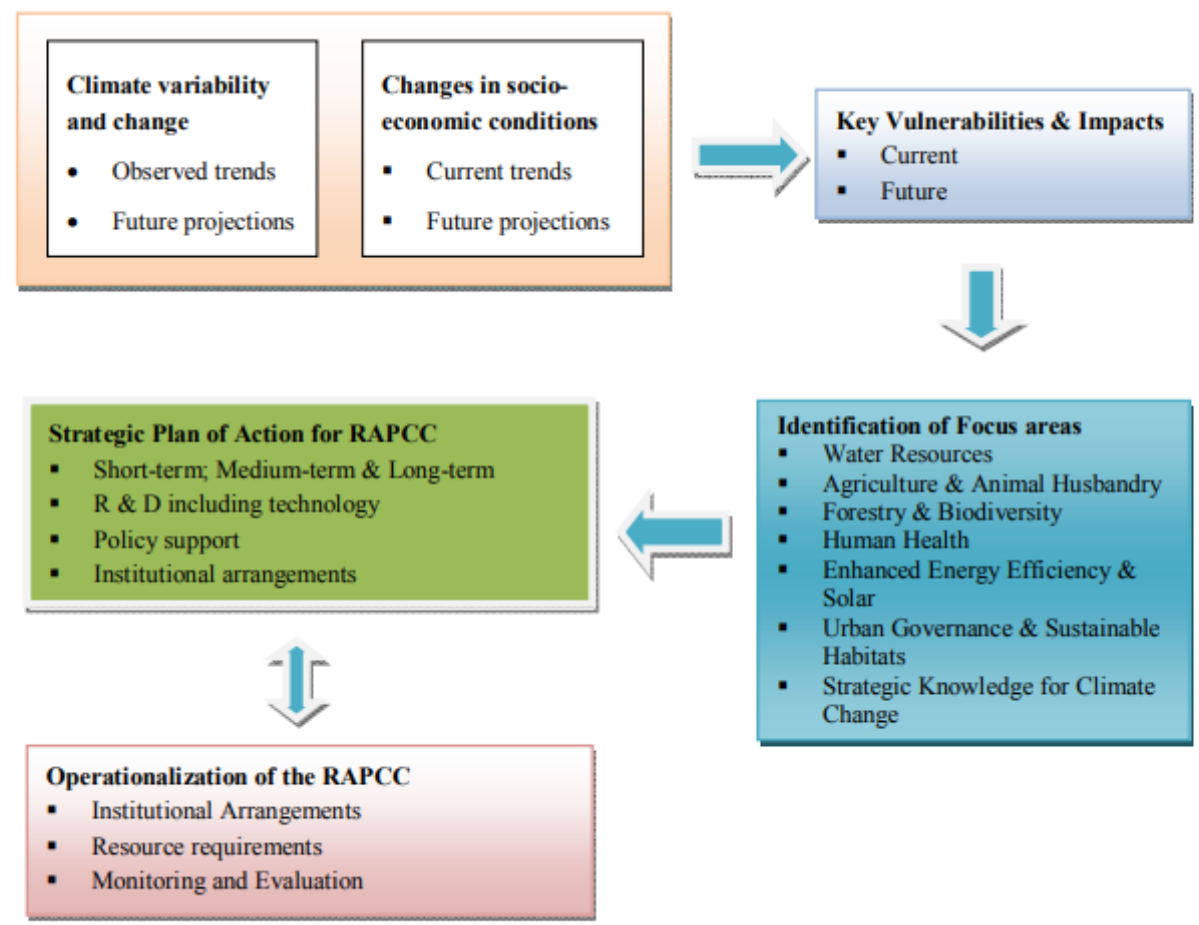




\section{An Overview of Rajasthan:-}

\begin{tabular}{cllr}
\hline SI No. & Indicators & Rajasthan & \% of India \\
\hline 1 & Area & $3,42,000$ sq. km. & 10.4 \\
2 & Population & 56.5 million & 5.49 \\
3 & Rural population & 43.2 million & 5.8 \\
4 & Total forest cover & 32,627 sq. km. & 4.19 \\
5 & Gross cropped area & $2,16,99,000$ hectare & 11.25 \\
6 & Net sown area & $1,68,36000$ hectare & 11.87 \\
7 & Net irrigated area & $62,94,000$ hectare & 10.46 \\
8 & Livestock & 49 million & 10.13 \\
9 & Food grain production & $1,14,45,000$ tonnes & 5.49 \\
10 & Oilseed production & $59,64,000$ tonnes & 21.31 \\
11 & Rainfall & $57.5 \mathrm{~cm}$ (annual average) & \\
\hline
\end{tabular}

\section{Positive impacts of Agro Tourism:-}

It is essential to cultivate our lands in a sustainable way for the foreseeable future since, now a day's climatic changes becomes very vulnerable.

Both domestic and foreign tourism help in making farmers and villagers and other public aware about the consequences which can be caused by change in climatic and environmental conditions and that how much effect of that change is causing harm to our natural resources such as land, water, air, forests, etc.

By taking initiatives in Agro tourism Tourists, visitors, farmers and local people can exchange their skills and knowledge on farming and agriculture. This will also brings monetary benefits to them and improves climatic conditions too. Thus provides a better place with a better environment and surroundings.

And the revenue generated by government from tourism can be utilized to fund more research regarding sustainable and eco-friendly farming.

Some have already established agro tourism sites and farms- animal feeding, hands-on-pottery, cattle ranch, agri-fairs, etc.

\section{Government Initiatives in Ago Tourism sector:-}

Government launches various policy initiatives and provides institutional support to promote agro tourism sector. In 2015 Rajasthan state government launched Rajasthan Tourism Unit Policy 2015 which promotes investment and public to engage in tourism activities.

Government also brings their focus on theme based tourism products i.e., Cultural, Dessert, Heritage, Wildlife, Spiritual, etc. To promote Rajasthan as a single pack with variety of flavours, as all season tourist's destination.

For development of tourism, government earmarked his properties/ land in various parts of state.

Rajasthan tourism replaced its earlier slogan "jaanekyadikhjaye" with the state's old slogan "padharomharedesh". And department logo is 'Rajasthan- theincredible state of India'.

Based on Geography, Coverage and Attraction, Rajasthan has its nine circuits which are developed with the assistance of central government. Apart from this Rajasthan is a part of well established tourist circuit that includes New Delhi, Agra and Jaipur, Golden triangle one of the most visited circuits.

According to the World Bank's ranking of 'Ease of doing Business' Rajasthan ranks \#6 in India.

\section{Findings}

1. Agro tourism helps in sustainable development and also provides an additional source of income.

2. People do not know much about this, they don't know what to expect from the agro-tourism activity.

3. Government is also taking initiatives in this regard to educate the people and earn extra profits. 
4. Revenue generated from this by government is used for research purpose to find sustainable and eco friendly farming.

\section{Conclusion}

It is just an experiment to find out whether the people are aware about this concept, additional income benefits and initiatives taken by government in this regard. So many agro tourist sites which provide a life time experience to its visitors and tourists. And, an additional sources of income for government and localities. But it is seen that it will be great if proper training is provided that is morally, ethically and culturally. And let them realize that they are their income source and also benefits nature and provides healthy food too

\section{References}

Carla Barbieri, P. S. (2011). Perceived Benefits of Agritourism: A Comparison. 2011 ttra International Conference (p. 11). 2011: University of Massachusetts Amherst.

Felicetti, S. A. (2013). The Potential of Agritourism in Revitalizing Rural Communities: Some Empirical Results. University of Calabria : P. Bucci, 42\C, 87036 Rende (CS), Italy.

Pulinkalayil, P. (2016). Rajasthan to promote agri-tourism in big way. The Times Of India .

Reza, s. (2018). Why we should invest in agro-tourism. Bangladesh: Dhaka Tribune.

S, M. (2017). AgriTourism facility for tourists in Udaipur. Udaipur Times .

Sarkar, S. (December 2010). agri tourism in India- A Way of Rural Development. AJTS, vol.5 .

SRIVASTAVA, D. S. (2016). Agritourism as a Strategy for the Development of Rural Areas Case Study of Dungrajya Village, Southeast Rajasthan, India. Quest Journals Journal of Medical and Dental Science Research , 39.

Strategic Government Advisory (SGA), Y. B. (2016). Agritourism: Advantage Rajasthan. Global Rajasthan Agritech Meet, Jaipur , 48.

Tiraieyari, N. (2012). Agri-tourism: Potential opportunities for farmers and local communities in Malaysia. African journal of agricultural research .

Reza, S. (2017). The many benefits of agro-tourism. The Daily Star. 